\title{
Effects of mulching for water conservation on soil carbon, nitrogen and biological properties
}

\author{
Xiaomin PI ${ }^{1}$, Tongxun ZHANG ${ }^{1}$, Benhua SUN $(\bowtie){ }^{1,2}$, Quanhong CUI ${ }^{1}$, Yun GUO ${ }^{1}$, Mingxia GAO $^{3}$, \\ Hao FENG $^{2,3,4}$, David W. HOPKINS ${ }^{5}$
}

1 Key Laboratory of Plant Nutrition and the Agri-environment in Northwest China of Ministry of Agriculture/College of Natural Resources and Environment, Northwest A\&F University, Yangling 712100, China

2 Institute of Water Saving Agriculture in Arid Areas of China, Northwest A\&F University, Yangling 712100, China

3 College of Water Resources and Architectural Engineering, Northwest A\&F University, Yangling 712100, China

4 Institute of Water and Soil Conservation, Chinese Academy of Sciences and Ministry of Water Resources, Yangling 712100, China

5 The Royal Agricultural University, Cirencester, Gloucestershire GL76JS, UK

\begin{abstract}
The effect of mulching with straw, white plastic film and black plastic film for improving soil water storage and on the soil properties was examined in a wheat-maize rotation system on Loess soil in northwestern China. All the mulches improved the water storage to some extent and led to warmer soils. However, the organic $\mathrm{C}$ and total $\mathrm{N}$ contents of the soils declined significantly under the mulches, particularly the plastic film mulches, and this could have long-term detrimental effects on soil quality and the sustainability of the some mulching practices.
\end{abstract}

Keywords biomass, carbon, mulch, nitrogen, plastic films, soil, straw, water storage

\section{Introduction}

By 2050, global grain demand is projected to double from that at the beginning of the century ${ }^{[1]}$, yet there will be limited or no increase in cropping area or water for irrigation and there may even be reductions in both. The situation is serious in China where only $0.1 \mathrm{hm}^{2}$ of cropland is available per person ${ }^{[2]}$. Growing population and consumption in China drive agricultural innovation to improve food production and sustainable development of agriculture. Meeting the demand for increased grain production requires improved productivity in existing cropping systems $^{[2,3]}$. In situ soil and water management is a feasible way of improving dryland agricultural produc-

Received September 21, 2016; accepted December 6, 2016

Correspondence: sunbenhua@126.com tivity $^{[4]}$. An example being cultivation with surfacemulching (i.e., covering the soil surface between the crop plants with a permeable or impermeable material), such as straw $^{[5,6,7,8]}$ or plastic-film ${ }^{[9,10]}$. Mulching with straw significantly improves water use efficiency by reducing water evaporation from the soil surface, and also affects soil temperatures and crop yields ${ }^{[6,11-13]}$. Mulching with plastic film also improves water use efficiency but also directly changes soil biological characteristics and fertility because, unlike straw mulching, it is impermeable and does not add any organic matter or nutrients ${ }^{[14,15]}$. Research aimed understanding the processes that affect crop productivity as a result of mulching is needed, because most of the biogeochemical processes are not yet sufficiently understood and short term benefits should not be traded against longer-term soil degradation ${ }^{[16,17]}$.

In this research, the aim were to (1) investigate the effects of different mulching materials on soil temperature, water content and storage; (2) compare soil fertility parameters especially soil organic carbon and nitrogen under different mulching materials; and (3) suggest optimum mulching approaches for wheat-maize rotational cultivation on Eum-Orthric Anthrosols (Lou soil) in the semi-arid Loess Plateau of China.

\section{Materials and methods}

\subsection{Experimental site}

An experiment was established at the Irrigation Experimental Station of the Key Laboratory of Agricultural Soil and Water Conservation Engineering in Arid Areas (Ministry of Education), at the Northwest A\&F University 
near Yangling in Shaanxi Province in the northwestern China $\left(108^{\circ} 24^{\prime} \mathrm{E}, 34^{\circ} 20^{\prime} \mathrm{N}\right)$. The site is at $521 \mathrm{~m}$ above sea level with the typical Eum-Orthric Anthrosols soils of the Loess Plateau. The site has a semi-arid climate with $12.9^{\circ} \mathrm{C}$ mean annual temperature. There is $660-680 \mathrm{~mm}$ per annum rainfall, most of which falls in the late summer (July to September) with dry conditions during the winter (December and January). The soil at the site has silt loamy texture, soil organic $\mathrm{C}$ of $8.26 \pm 0.25 \mathrm{~g} \cdot \mathrm{kg}^{-1}$ soil, total $\mathrm{N}$ of $0.95 \pm 0.03 \mathrm{mg} \cdot \mathrm{kg}^{-1}$ soil and $\mathrm{pH} 8.02 \pm 0.04$ in the surface $(0-20 \mathrm{~cm})$ horizons. A two phase rotation of winter wheat, sown in October and harvested in May, followed by summer maize, sown in June and harvested in September, is typical for the region (Table 1). Weather data for the site was obtained from a recording station located within $50 \mathrm{~m}$ of the experimental plots.

\subsection{Experimental design}

The design comprised the following treatments:

(1) Control;

(2) Mulching with wheat straw $\left(4 \mathrm{t} \cdot \mathrm{hm}^{-2}\right)$ after sowing in both phases of the rotation;

(3) Mulching with white polythene film $(0.008 \mathrm{~mm}$ thickness) between the rows of plants in both phases of the rotation;

(4) Mulching with black polythene film $(0.008 \mathrm{~mm}$ thickness) between the rows of plants in both phases of the rotation.

Thus, in the control, rain water infiltrated the soil and could evaporate from the soil surface without a mulch barrier. In the straw mulch treatment, rain water could penetrate the mulch, which also impeded evaporation from the soil surface. By contrast, in the plastic film treatments, rain water ran off the surface of the film and entered the soil along the planted rows at the edges of the film, and evaporation from the soil surface was restricted to a narrow region along the rows. Between each phase of the rotation, the straw mulch and polythene covers were removed at harvest time and the soil was cultivated at the start of each phase of the rotation. The timing of the phases of the rotation used for this experiment and the soil sampling dates are shown in Table 1. The four treatments (control, straw mulch, white film and black film) were established on plots 5 by $2 \mathrm{~m}$ replicated three times and laid out in a randomized block design. The sowing density was $30 \mathrm{~cm}$ row spacing for the wheat, and $30 \mathrm{~cm}$ plant space and $60 \mathrm{~cm}$ row spacing for the maize. For winter wheat, fertilizer $\mathrm{N}$ and $\mathrm{P}$ at $120 \mathrm{~kg} \mathrm{~N}$ per hectare and $100 \mathrm{~kg} \mathrm{P} \mathrm{O}_{5}$ per hectare as urea and single superphosphate were applied at sowing and $30 \mathrm{~kg} \mathrm{~N}$ per hectare applied by top dressing soon after emergence. For summer maize, fertilizer $\mathrm{N}$ and $\mathrm{P}$ were applied at $225 \mathrm{~kg} \mathrm{~N}$ per hectare and $90 \mathrm{~kg} \mathrm{P}_{2} \mathrm{O}_{5}$ per hectare. Soil temperatures were measured continuously at $1 \mathrm{~h}$ intervals in one plot per treatment with 5TE probes and data loggers (Degacon Em50, Degacon Devices, Pullman, WA, USA) installed at a depth of $30 \mathrm{~cm}^{[18]}$.

\subsection{Soil sampling and analyses}

In the first week of October 2014, immediately after the summer maize had been harvested, soil samples were collected. A soil sampling pit $2 \mathrm{~m}$ deep was excavated in each plot and volume-specific soil samples were collect from each at $20-\mathrm{cm}$ increments down to $200 \mathrm{~cm}$. A subsample of soil from each depth was dried at $105^{\circ} \mathrm{C}$ in a fan-assisted oven for $24 \mathrm{~h}$ and the water content estimated gravimetrically. The soil bulk density was determined from the mass of dry soil per unit volume, which was then used for estimates of area-based or volumetric soil water content.

The soil organic $\mathrm{C}$ and total $\mathrm{N}$ contents were determined on air-dried and ground subsamples of soil from the 0-20 $\mathrm{cm}$ depth using the potassium dichromate volumetric ${ }^{[19]}$ and Kjeldahl ${ }^{[20]}$ methods. The soil $\mathrm{NO}_{3}{ }^{-} \mathrm{N}$ was extracted from the soil by shaking samples in $1 \mathrm{~mol} \cdot \mathrm{L}^{-1}$ $\mathrm{KCl}(1: 5(\mathrm{w} / \mathrm{w})$ soil: $\mathrm{KCl}$ solution) for $1 \mathrm{~h}$ and then filtered. The filtrate was analyzed for $\mathrm{NO}_{3}{ }^{-} \mathrm{N}$ with a Chemlab Auto-Analyzer ${ }^{[21]}$.

Microbial biomass $\mathrm{C}$ and $\mathrm{N}$ contents was determined by the chloroform-fumigation extraction method ${ }^{[22]}$. Fresh soil equivalent to $10 \mathrm{~g}$ oven-dried soil was fumigated for $24 \mathrm{~h}$ with ethanol-free chloroform and then extracted with $0.5 \mathrm{~mol} \cdot \mathrm{L}^{-1} \quad \mathrm{~K}_{2} \mathrm{SO}_{4}$. The same amount of soil was extracted without fumigation. The dissolved organic contents of the soil extracts were measured using TOC$\mathrm{V}_{\mathrm{CPH}}$ (Shimadzu, Japan), and the total $\mathrm{N}$ contents of the extracts were analyzed using peroxide potassium sulfateultraviolet spectrophotometry ${ }^{[23]}$.

\subsection{Statistical analyses}

All the results were shown as means of three replicates with standard error. The data were subjected to an ANOVA and Duncan's multiple range tests for evaluation of the mulching effects. Significant differences were reported at $P<0.05$ level. All of these data were analyzed with SPSS 16.0 (IBM Analytics, Armonk, NY, USA).

Table 1 Dates of rotations and soil sampling

\begin{tabular}{lcccc}
\hline Rotation phase & Crop & Start date (DD-MM-YY) & End date (DD-MM-YY) & Soil sampling period (DD-MM-YY) \\
\hline 1 & Winter wheat & $01-10-13$ & $31-05-14$ & $01-10-14$ to 07-10-14 \\
2 & Summer maize & $01-06-14$ & $30-09-14$ & 0 \\
\hline
\end{tabular}




\section{Results}

\subsection{Soil temperature}

In the control treatment, the mean annual soil temperature was $15.8^{\circ} \mathrm{C}$, which was higher than the annual air temperature, and over the year the soil ranged from 2.0 to $33.4^{\circ} \mathrm{C}$ (Table 2). The mulching treatments had no effect on the mean annual soil temperature, but did affect the minimums and maximums. The straw mulch reduced the temperature by slightly decreasing the maximum soil temperature and slightly increasing the minimum soil temperature compared to the control. Both the white and black film treatments led to increases in the maximum soil temperatures and either no or only minor effects on the minimum soil temperature compared to the control. Over the year, the total thermal time values ranged between 5017 and $5429{ }^{\circ} \mathrm{C} \cdot \mathrm{d}$ for the different treatments and the variation between treatments was no more than $8 \%$. The straw mulch led to a lower thermal time value than the control and the white film had a higher thermal time than the control, while the black film was only slightly lower than the control. Although the overall effects of the mulching treatments on temperature were relatively small, the mulching treatments affected the rates at which the soil temperature changed (Fig. 1). The straw mulch treatment warmed and cooled at similar rates to the control, while the white and black film treatments warmed and cooled more rapidly than the control (Table 3 ).

\subsection{Rainfall}

The rainfall during the experiment (October 2013 to September 2014) was $686 \mathrm{~mm}$, of which $288 \mathrm{~mm}$ fell during the 8-month winter wheat phase and 397 fell during the 4-month summer maize phase (Table 4). There was no rainfall during the two mid-winter months of December and January.

Table 2 Temperature conditions in soil for the control and mulching treatments

\begin{tabular}{lcccc}
\hline Phase in rotation & Control & Straw & White film & Black film \\
\hline Mean annual temperature $/{ }^{\circ} \mathrm{C}$ & 15.8 & 15.9 & 16.2 & 15.7 \\
Annual maximum $/{ }^{\circ} \mathrm{C}$ & 33.4 & 32.0 & 38.5 & 36.0 \\
Annual minimum $/{ }^{\circ} \mathrm{C}$ & 2.0 & 2.8 & 2.0 & 1.7 \\
Thermal time $/\left({ }^{\circ} \mathrm{C} \cdot \mathrm{d}\right)$ & 5314 & 5017 & 5429 & 5257 \\
\hline
\end{tabular}

(a)

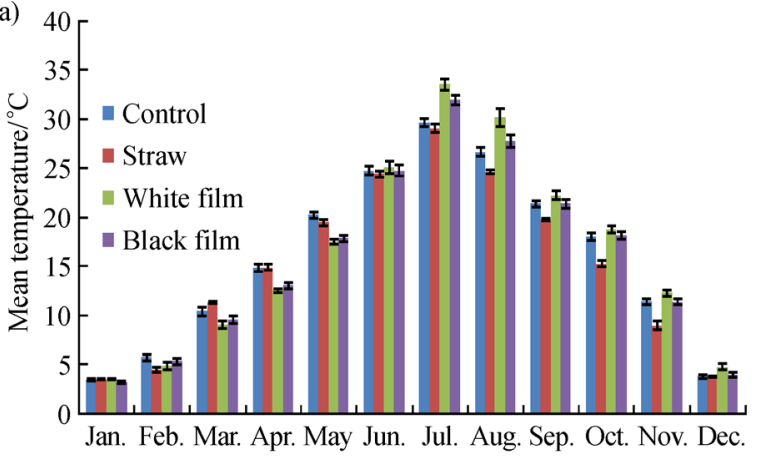

(c)

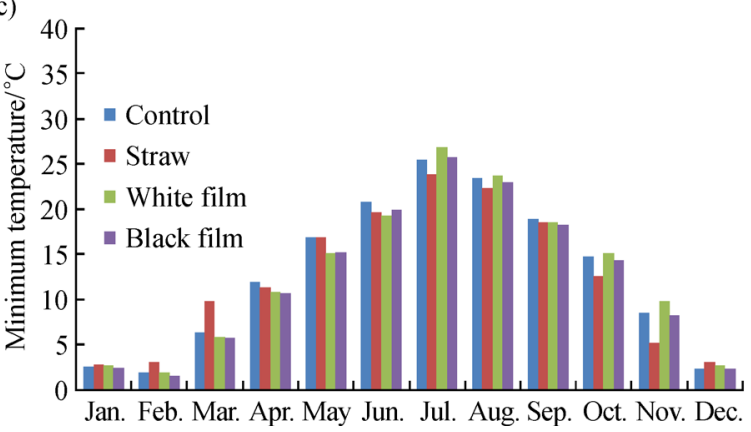

(b)

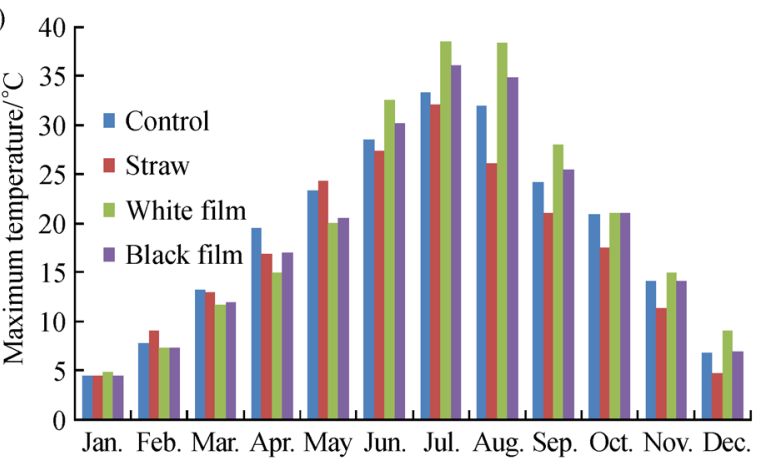

(d)

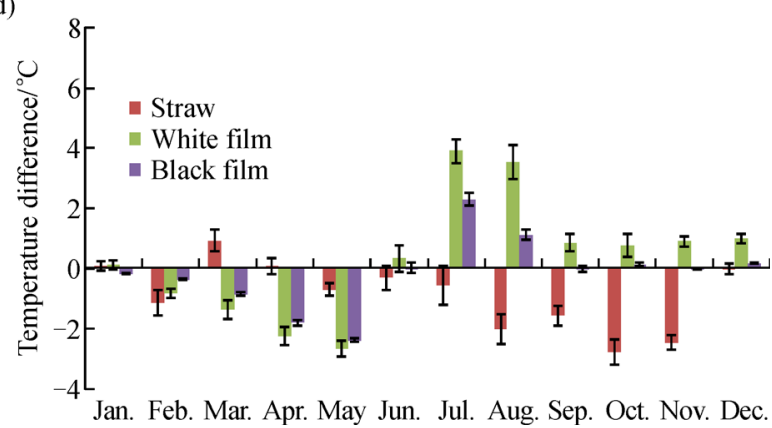

Fig. 1 Summary of soil temperatures during the experiment for the control and the different mulching treatments. (a) Mean temperature; (b) maximum temperature; (c) minimum temperature; (d) temperature difference relative to control. 
Table 3 Rates of change of soil temperatures for the control and mulching treatments

\begin{tabular}{|c|c|c|c|c|c|c|c|c|c|}
\hline \multirow{2}{*}{ Item } & \multicolumn{4}{|c|}{ Increase rate during January to July $/\left({ }^{\circ} \mathrm{C} \cdot \mathrm{d}^{-1}\right)$} & \multicolumn{4}{|c|}{$R^{2}$} & \multirow{2}{*}{$n$} \\
\hline & Control & Straw & White film & Black film & Control & Straw & White film & Black film & \\
\hline Monthly mean & 0.163 & 0.161 & 0.187 & 0.176 & 0.99 & 0.99 & 0.95 & 0.97 & 7 \\
\hline Monthly maximum & 0.177 & 0.168 & 0.217 & 0.195 & 1.00 & 0.99 & 0.94 & 0.97 & 7 \\
\hline Monthly minimum & 0.154 & 0.135 & 0.156 & 0.154 & 0.97 & 0.98 & 0.95 & 0.96 & 7 \\
\hline \multirow{2}{*}{ Item } & \multicolumn{4}{|c|}{ Decrease rate during July to December $/\left({ }^{\circ} \mathrm{C} \cdot \mathrm{d}^{-1}\right)$} & \multicolumn{4}{|c|}{$\overline{R^{2}}$} & \\
\hline & Control & Straw & White film & Black film & Control & Straw & White film & Black film & \\
\hline Monthly mean & -0.187 & -0.183 & -0.208 & -0.199 & 0.98 & 1.00 & 0.99 & 0.99 & 6 \\
\hline Monthly maximum & -0.199 & -0.190 & -0.236 & -0.221 & 0.97 & 0.99 & 0.97 & 0.98 & 6 \\
\hline Monthly minimum & -0.173 & -0.170 & -0.172 & -0.171 & 0.98 & 0.96 & 0.98 & 0.99 & 6 \\
\hline
\end{tabular}

Table 4 Distribution of rainfall during the experiment

\begin{tabular}{|c|c|c|c|}
\hline Phase & Date (DD-MM) & Rainfall/mm & Rain days \\
\hline \multirow[t]{9}{*}{ Winter wheat } & $13-10$ & 35.7 & 4 \\
\hline & $13-11$ & 16.0 & 6 \\
\hline & $13-12$ & 0.0 & 0 \\
\hline & $14-01$ & 0.0 & 0 \\
\hline & $14-02$ & 28.0 & 16 \\
\hline & $14-03$ & 28.7 & 6 \\
\hline & $14-04$ & 142.0 & 13 \\
\hline & $14-05$ & 38.4 & 6 \\
\hline & Sub total & 288.8 & 51 \\
\hline \multirow[t]{6}{*}{ Summer maize } & $14-06$ & 51.3 & 11 \\
\hline & $14-07$ & 22.9 & 4 \\
\hline & $14-08$ & 108.6 & 11 \\
\hline & $14-09$ & 215.1 & 16 \\
\hline & Sub total & 397.9 & 42 \\
\hline & Total at soil sampling & 686.7 & 93 \\
\hline
\end{tabular}

\subsection{Soil water storage}

At the end of the experiment, the pattern of soil water distribution in the soil increased with depth (Fig. 2). The effect of all the mulching treatments was to increase the soil water storage significantly compared to the control, with the white and black film treatments having a significantly greater effect than the straw mulch (Fig. 2a). The soil volumetric water content ranged between 0.15 and $0.24 \mathrm{~g} \cdot \mathrm{cm}^{-3}$, and was greatest toward the top and the base of the profile, and least in middle of the profile (Fig. 2b).

\subsection{Soil organic carbon and total nitrogen contents}

The three mulching treatments significantly reduced soil organic $\mathrm{C}$ relative to the control (Fig. 3). The reduction of organic $\mathrm{C}$ ranged between 2.1 and $2.8 \mathrm{~g} \cdot \mathrm{kg}^{-1}$ soil or between $20 \%$ and $26 \%$ of the control value, but there were no significant differences between the mulching treatments (Fig. 3). The effects of the mulching treatment on soil total $\mathrm{N}$ were also significant reductions, but the differences were smaller than those observed for soil organic $\mathrm{C}$ (Fig. 3). The differences of total $\mathrm{N}$ ranged from 55 to $110 \mathrm{mg} \cdot \mathrm{kg}^{-1}$, and the negative effect of the white and black film mulches on soil $\mathrm{N}$ was significantly greater than for the straw mulch (Fig. 3).

\subsection{Soil microbial biomass carbon and nitrogen contents}

The three mulching treatments significantly reduced microbial biomass relative to the control (Fig. 4). The reduction of biomass $\mathrm{C}$ ranged between 95 and $230 \mathrm{mg} \cdot \mathrm{kg}^{-1}$ soil and that of biomass $\mathrm{N}$ ranged between 15 and $22 \mathrm{mg} \cdot \mathrm{kg}^{-1}$ soil. For biomass $\mathrm{C}$, the differences were smallest for the straw mulch and greater for the white and the black films, with the effect of the black film being 

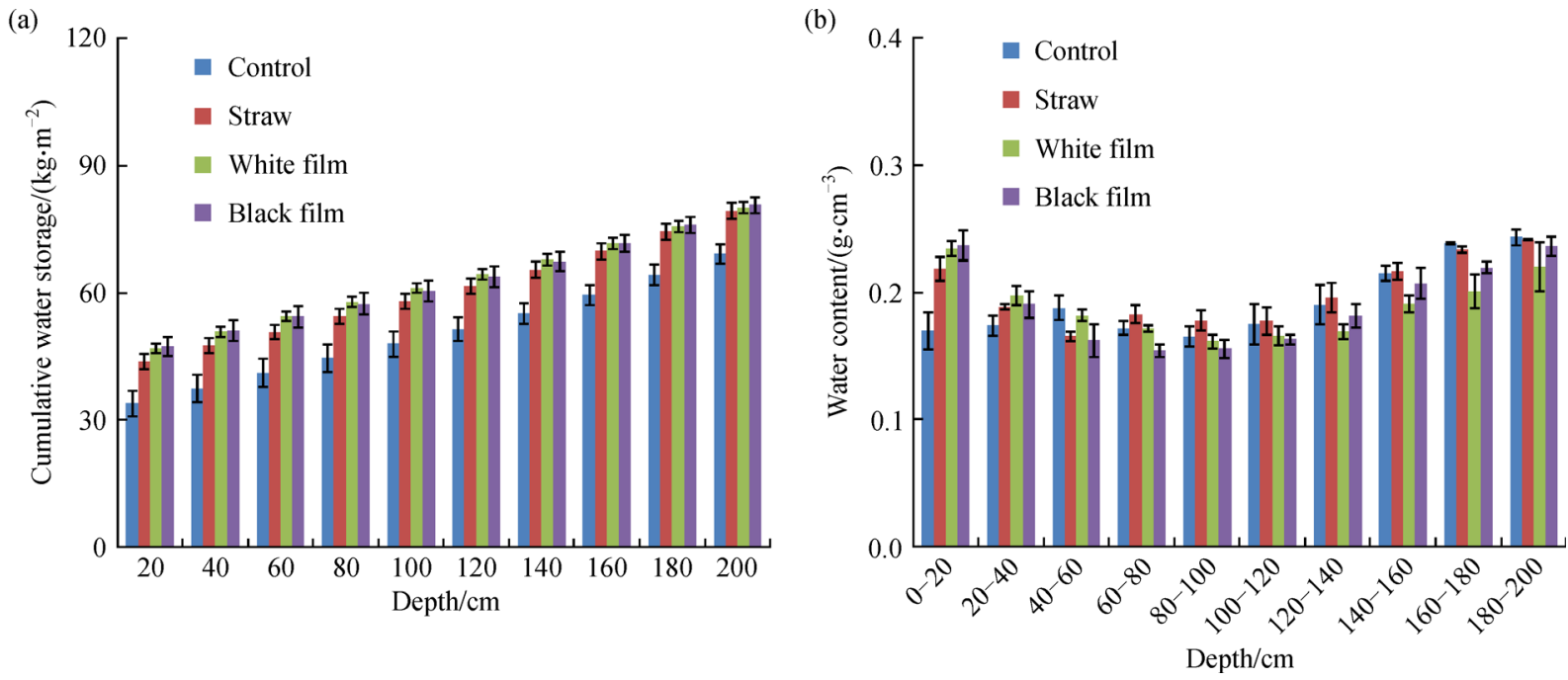

Fig. 2 Distribution of water with depth for the control and mulching treatments at the end of the experiment. (a) Cumulative water storage to $2 \mathrm{~m}$ depth; (b) soil volumetric water content.

significantly more than for the white film (Fig. 4a). The effects of the mulching treatments on biomass $\mathrm{N}$ were similar to biomass $\mathrm{C}$ except that there was no significant difference between the straw mulch and the white film treatment (Fig. 4b).

\subsection{Soil nitrate content and distribution with depth}

Nitrate content in the control increased with depth to 80 $100 \mathrm{~cm}$ and declined with increasing depth below $100 \mathrm{~cm}$ (Fig. 5). In all mulch treatments, the maximum $\mathrm{NO}_{3}{ }^{-} \mathrm{N}$ contents also occurred at $80-100 \mathrm{~cm}$, but the $\mathrm{NO}_{3}{ }^{-} \mathrm{N}$ contents at $0-20 \mathrm{~cm}$ were greater than the control in all cases (Fig. 5). The total $\mathrm{NO}_{3}{ }^{-} \mathrm{N}$ in the profile ranged from 18 to $21 \mathrm{~g} \cdot \mathrm{m}^{-2}$, but did not differ significantly between any of the treatments.

\section{Discussion}

The three mulches in this experiment had different effects

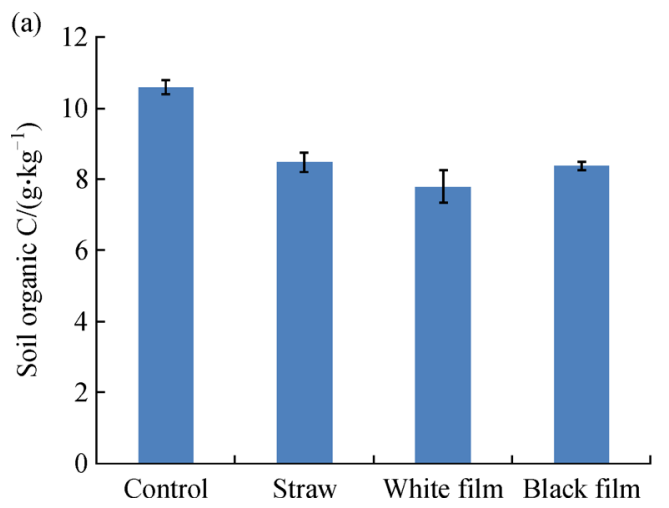

on soil temperature. Several investigators have reported that the soil thermal regime under straw mulching was different from that of bare soil, with soil temperatures often being lower under mulched surfaces than in non-mulched soils $^{[24,25]}$. This was because straw covering of the soil surface has a higher albedo and lower thermal conductivity than bare soil, which reduces the solar energy reaching the soil thereby reducing the magnitude of temperature increases in the summer ${ }^{[26]}$. By contrast, the slightly higher minimum temperature under the straw mulch is likely to be due to the thermal insulation effect of the straw during the winter. Soil temperature under the film mulches on the other hand were higher than the control from July to December and the black film was not as effective in raising soil temperatures (Fig. 1), which may have been due to the lower light transmission of black film ${ }^{[27]}$. Subrahmaniyan and $\mathrm{Zhou}^{[28]}$ also found that soil temperature were highest under transparent film mulch, followed by degradable film and then black polyethylene film mulches.

Mulching increased the soil water content presumably as a result of reduced evaporation ${ }^{[29]}$. Furthermore, the

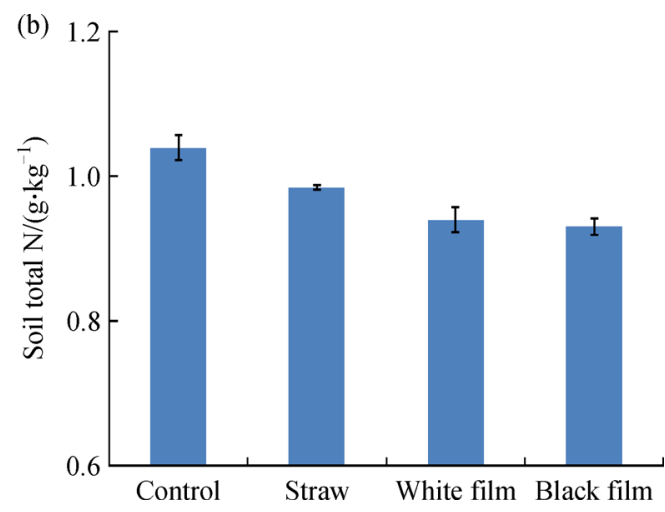

Fig. 3 Soil organic C (a) and total N (b) contents for the control and mulching treatments at the end of the experiment 

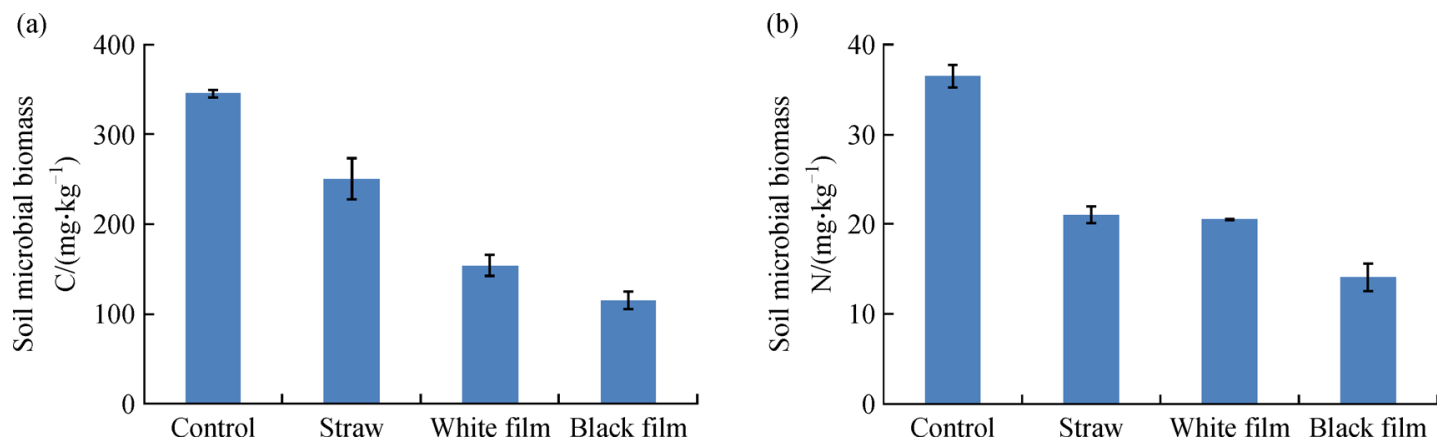

Fig. 4 Soil microbial biomass $\mathrm{C}$ (a) and N (b) for the control and mulching treatments at the end of the experiment

(a)

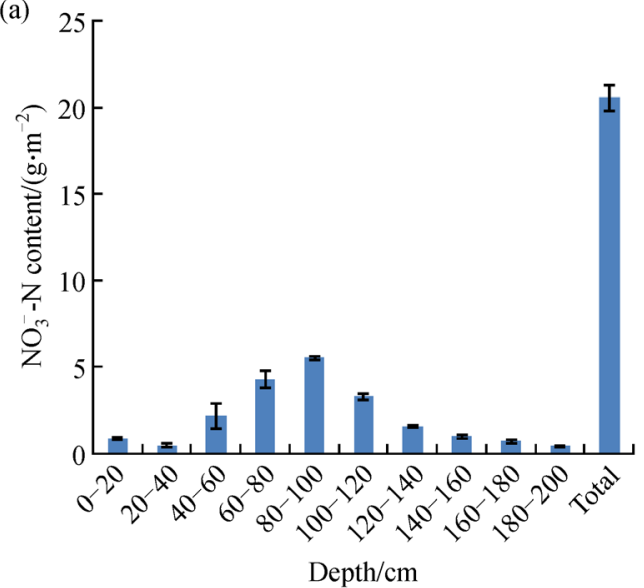

(c)

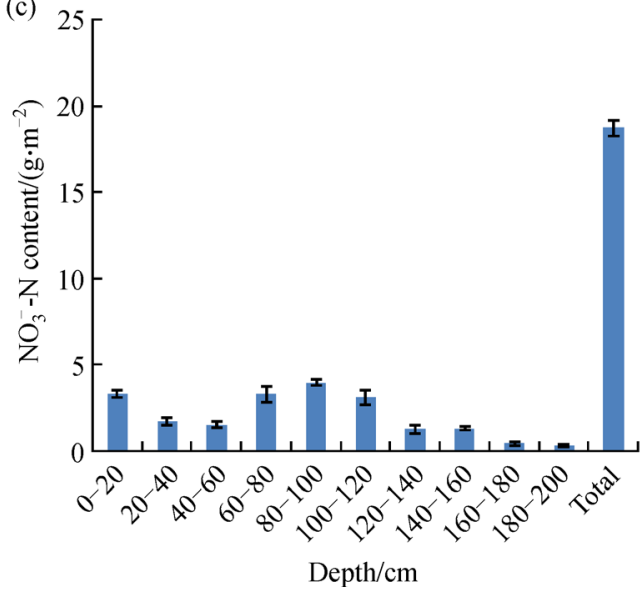

(b)

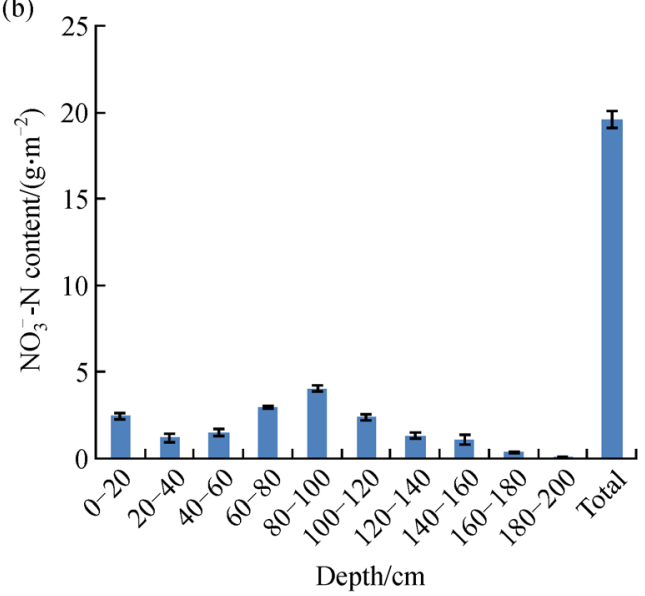

(d)

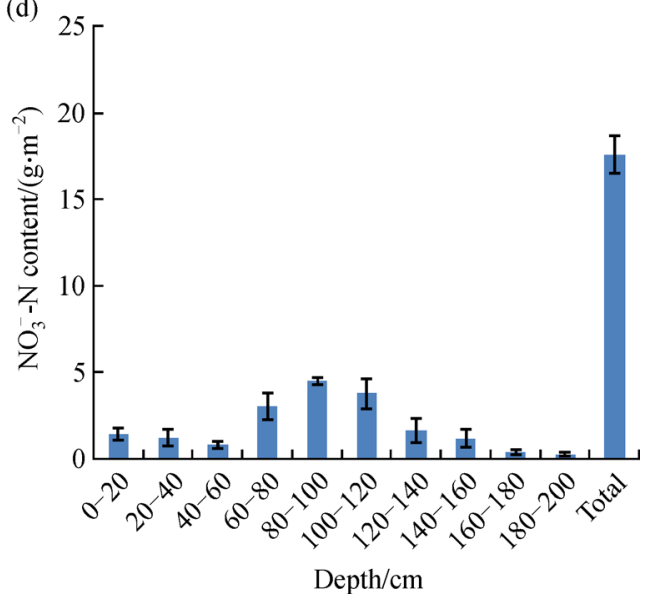

Fig. 5 Distribution and total content of $\mathrm{NO}_{3}{ }^{-}-\mathrm{N}$ in the soil for the control and the mulching treatments at the end of the experiment. (a) Control; (b) straw; (c) white film; (d) black film.

collection and infiltration pathway, particularly for the plastic film treatments, was likely to have led to more efficient delivery of rainwater to the roots. Our observation of greater water content under the mulches is consistent with the observations of Cheng et al. ${ }^{[29]}$ and Jiang et al. ${ }^{[30]}$. The elevated $\mathrm{NO}_{3}{ }^{-} \mathrm{N}$ concentrations near the soil surface are likely to be the result of reduced water infiltration and flow beneath the mulches, therefore reduced leaching.
Given the central role of soil organic C in several soil biological, chemical and physical processes that affect soil fertility and the maintenance of soil fertility, a change in soil organic $\mathrm{C}$ is a key parameter in judging the sustainability of mulching treatments ${ }^{[31,32]}$. However, the data in this experiment are from a one-year investigation and this is a very limited time period for organic matter changes $^{[33,34]}$, so large changes are not expected. Soil 
organic carbon in the three mulching treatments were significantly lower than that of the control, which is contrary to the observations of Guan et al. ${ }^{[35]}$ and Liang et al. ${ }^{[36]}$. Their results showed that the soil organic matter under straw mulch was higher than that of the control, mainly because the soil organic $\mathrm{C}$ was enhanced by the decay of mulched straw. In our study, however, the soil sample was taken from beneath the mulch a year after it had been applied. Over this period, some of the soil organic matter would have decomposed in the moister and less extreme winter temperature created by the straw mulch compared to the control ${ }^{[37,38]}$. Whatever the mechanism, it is obvious that insufficient organic $\mathrm{C}$ from the straw had mixed into the underlying soil to have a detectable effect on soil organic $\mathrm{C}$, which could have been due to reduced water flow under the straw mulch. Our findings for the soil organic $\mathrm{C}$ contents beneath the plastic film mulches are, however, consistent with the findings of Guan et al. ${ }^{[35]}$ and Liang et al. ${ }^{[36]}$, who showed that the soil organic C declined significantly under white or black plastic film compared with the control. Reduced organic $\mathrm{C}$ input at the soil surface in the plastic mulches is almost certainly a key determinant of the lower soil $\mathrm{C}$ contents. Furthermore, Guo et al. ${ }^{[27]}$ showed a greater decline in soil organic $\mathrm{C}$ under the white film compared to the black film because of a more favorable temperature regime for decomposition, which is consistent with our observation of a lower soil organic $\mathrm{C}$ beneath the white film compared to the black film. Many of the same observations and discussion points mentioned for soil organic $\mathrm{C}$ apply equally to soil total $\mathrm{N}$.

Although the soil microbial biomass is only a small fraction of the soil organic $\mathrm{C}$ or $\mathrm{N}$ pools, it is a key indicator of soil biological activity and fertility status ${ }^{[39]}$. In this study, the soil microbial biomass content under the mulches were all significantly lower than for the control, which is consistent with the observations of Zhang et al. ${ }^{[40]}$ and also consistent with increased biological activity leading to organic matter decomposition under mulches because of the more favorable environment for decomposition $^{[27,41]}$. Dong et al. ${ }^{[42]}$ have reported greater soil microbial biomass beneath straw mulches, which we did not observe, but this is likely to be due to limited organic $\mathrm{C}$ mixing with the soil at the depth of our sample, as previously mentioned.

\section{Conclusions}

In this study we have shown that the mulches all had the expected effects on water storage and temperature in the soil. However, the benefits of mulching need to be evaluated not just in relation to these properties, because our data also indicate depletion in the soil organic $\mathrm{C}$, total $\mathrm{N}$ and microbial biomass particularly under the plastic mulches. These are key soil parameters, which are drivers of soil fertility and its long-term maintenance. If the short- term benefits of mulching on water retention and storage are offset by deterioration of properties such as organic matter turnover, nutrient release during mineralization, stabilization of soil structure by organic matter and microbial growth, and water absorption by soil organic matter, it is possible that the benefits of mulching, particularly with plastic films, can be short lived and in the longer term there may be a detrimental effect on soil properties and the ability of the soil to sustain crop growth.

Acknowledgements This study was financially supported by the National High-tech R\&D Program of China (2013AA102904, 2011AA100503), the Sci-tech Coordination and Innovation Project of Shaanxi Province (2016KTZDNY03-06), and Chinese "111" Project (B12007). The manuscript was completed while Dr. Benhua Sun was an academic visitor supported by the Chinese Scholarship Council at Royal Agricultural University, UK.

Compliance with ethics guidelines Xiaomin Pi, Tongxun Zhang, Benhua Sun, Quanhong Cui, Yun Guo, Mingxia Gao, Hao Feng, and David W. Hopkins declare that they have no conflict of interest or financial conflicts to disclose.

This article does not contain any studies with human or animal subjects performed by any of the authors.

\section{References}

1. Tilman D, Balzer C, Hill J, Befort B L. Global food demand and the sustainable intensification of agriculture. Proceedings of the National Academy of Sciences of the United States of America, 2011, 108(50): 20260-20264

2. Zhang F, Chen X, Vitousek P. Chinese agriculture : an experiment for the world. Nature, 2013, 497(7447): 33-35

3. Godfray H C J, Beddington J R, Crute I R, Haddad L, Lawrence D, Muir J F, Pretty J, Robinson S, Thomas S M, Toulmin C. Food security: the challenge of feeding 9 billion people. Science, 2010, 327(5967): 812-818

4. de Fraiture C, Wichelns D, Rockstrm J, Kemp-Benedict E, Eriyagama N, Gordon L J, Hanjra M A, Hoogeveen J, Huber-Lee A, Karlberg L. Looking ahead to 2050: scenarios of alternative investment approaches. In: Molden D, ed. Water for food, water for life: a comprehensive assessment of water management in agriculture. London: International Water Management Institute, 2007, 91-145

5. Dahiya R, Ingwersen J, Streck T. The effect of mulching and tillage on the water and temperature regimes of a loess soil: experimental findings and modelling. Soil \& Tillage Research, 2007, 96(1-2): 5263

6. Zhang S, Lövdahl L, Grip H, Tong Y, Yang X, Wang Q. Effects of mulching and catch cropping on soil temperature, soil moisture and wheat yield on the Loess Plateau of China. Soil \& Tillage Research, 2009, 102(1): 78-86

7. Wang H, Liu Q R, Zhang S Y, Shen J Y, Zhao D D, Yu J P, Li Q Q. Grain yield and soil water content of super-high-yield summer maize under straw mulching. Journal of Soil and Water Conservation, 2011, 25(5): 261-264 (in Chinese)

8. Tao Z, Li C, Li J, Ding Z, Xu J, Sun X, Zhou P, Zhao M. Tillage and straw mulching impacts on grain yield and water use efficiency of 
spring maize in Northern Huang-Huai-Hai Valley. Field Crops Research, 2015, 3(5): 445-450

9. Wang J, Zhang J, Xu X, Zhang X, Zhu F. Effect of plastic film mulching on soil fertility. Journal of Shenyang Agricultural University, 1992, 23(Z9): 32-37 (in Chinese)

10. Li S P, Cai Z C, Yang H, Wang J K. Effects of long-term fertilization and plastic film covering on some soil fertility and microbial properties. Acta Ecologica Sinica, 2009, 29(5): 2489-2498 (in Chinese)

11. Steiner J L. Tillage and surface residue effects on evaporation from soils. Soil Science Society of America Journal, 1989, 53(3): 911-916

12. Li S, Xiao L. Distribution and management of drylands in the People's Republic of China. Advances in Soil Science, 1992, 18(3): 147-302

13. Baumhardt R L, Jones O R. Residue management and tillage effects on soil water storage and grain yield of dryland wheat and sorghum for a clay loam in Texas. Soil \& Tillage Research, 2002, 68(2): 7182

14. Grassini P, Yang H, Cassman K G. Limits to maize productivity in Western Corn-Belt: A simulation analysis for fully irrigated and rainfed conditions. Agricultural and Forest Meteorology, 2009, 149 (8): 1254-1265

15. Liu C A, Li F R, Zhou L M, Feng Q, Li X, Pan C C, Wang L, Chen J L, Li X G, Jia Y, Siddique K H M, Li F M. Effects of water management with plastic film in a semi-arid agricultural system on available soil carbon fractions. European Journal of Soil Biology, 2013, 57(7): 9-12

16. Gao Q H, Lu X M. Effects of plastic film residue on morphology and physiological characteristics of tomato seedlings. Journal of Tropical and Subtropical Botany, 2011, 19(5): 425-429 (in Chinese)

17. Yan C, He W, Turner N C. Plastic film-mulch in Chinese agriculture: importance and problems. World Agriculture, 2014, 4(2): 32-36

18. Ma Y, Piao S, Sun Z, Lin X, Wang T, Yue C, Yang Y. Stand ages regulate the response of soil respiration to temperature in a Larix principis-rupprechtii plantation. Agricultural and Forest Meteorology, 2014, 184(1): 179-187

19. Bremner J M, Jenkinson D S. Determination of organic carbon in soil. I. Oxidation by dichromate of organic matter in soil and plant materials. Journal of Soil Science, 1960, 11(2): 394-402

20. Bremner J M. Nitrogen - Total. In: Sparks D L, Page A L, Helmke P A, Loeppert R H, Soltanpour P N, Tabatabai M A, Johnston C T, Sumner M E, eds. Methods of soil analysis part 3, chemical methods, SSSA Book Series No. 5. Madison: Soil Science Society of America, 1996, 1085-1121

21. Best E K. An automated method for determining nitrate-nitrogen in soil extracts. Queensland Journal of Agricultural and Animal Sciences, 1976, 33(2): 161-166

22. Vance E D, Brookes P C, Jenkinson D S. An extraction method for measuring soil microbial biomass C. Soil Biology \& Biochemistry, 1987, 19(6): 703-707

23. Liang B, Zhou J B, Yang X Y. Changes of soil microbial biomass carbon and nitrogen, and mineral nitrogen after a long-term different fertilization. Plant Nutrition and Fertilizer Science, 2010, 16(2): 321-326 (in Chinese)

24. Bristow K L. The role of mulch and its architecture in modifying soil temperature. Australian Journal of Soil Research, 1988, 26(2): 269280

25. Sarkar S, Paramanick M, Goswami S B. Soil temperature, water use and yield of yellow sarson (Brassica napus L. var. glauca) in relation to tillage intensity and mulch management under rainfed lowland ecosystem in eastern India. Soil \& Tillage Research, 2007, 93(1): 94-101

26. Horton R, Bristow K L, Kluitenberg G J, Sauer T J. Crop residue effects on surface radiation and energy balance-review. Theoretical and Applied Climatology, 1996, 54(1): 27-37

27. Guo X J, Han Z X, Ma F W. Effect of different mulching treatments on changes of soil properties, growth of fruit tree, and yield, and quality of fruit. Journal of Northwest A \& F University, 2013, 41(9): 112-118 (in Chinese)

28. Subrahmaniyan K, Zhou W. Soil temperature associated with degradable, non-degradable plastic and organic mulches and their effect on biomass production, enzyme activities and seed yield of winter rapeseed (Brassica napus L.). Journal of Sustainable Agriculture, 2008, 32(4): 611-627

29. Cheng Y X, Deng R C, Fang J, Liu J, Chen X P, Lu J Y, Yu X Z, Xu $\mathrm{KW}$. Effect of mulching and cultivation patterns on soil temperature and soil water of maize in Western edge of Sichuan Basin, China. Soils, 2015, 47(3): 608-616 (in Chinese)

30. Jiang Y, Shi C Y, Wang Z Z. Effects of plastic film mulching on arable layer soil temperature, moisture and yield of sweet potato. Chinese Journal of Eco-Agriculture, 2014, 22(6): 627-634 (in Chinese)

31. Li Z W, Nie X D, Chen X L, Lu Y M, Jiang W G, Zeng G M. The effects of land use and landscape position on labile organic carbon and carbon management index in red soil hilly region, southern China. Journal of Mountain Science, 2015, 12(3): 626-636

32. Fang X, Wang Q, Zhou W, Zhao W, Wei Y, Niu L, Dai L. Land use effects on soil organic carbon, microbial biomass and microbial activity in Changbai Mountains of Northeast China. Chinese Geographical Science, 2014, 24(3): 297-306

33. Hopkins D W, Waite I S, McNicol J W, Poulton P R, Macdonald A J, O'Donnell A G. Soil organic carbon contents in long-term experimental grassland plots in the UK (Palace Leas and Park Grass) have not changed consistently in recent decades. Global Change Biology, 2009, 15(7): 1739-1754

34. Powlson D S, Bhogal A, Chambers B J, Coleman K, Macdonald A J, Goulding K W T, Whitmore A P. The potential to increase soil carbon stocks through reduced tillage or organic material additions in England and Wales: a case study. Agriculture, Ecosystems \& Environment, 2012, 146(1): 23-33

35. Guan Z H, Li Q Y, Zhang R Z, Wang L, Zhang J. Effects of conservation tillage on readily oxidizable and total organic carbon in soil. Chinese Journal of Soil Science, 2014, 45(2): 420-426 (in Chinese)

36. Liang Y C, Wang J, Liu Q Q, Lun W Z. Effects of soil surface mulching on soil organic carbon and its fractions in a wheat field in loess plateau, China. Ganhan Diqu Nongye Yanjiu, 2015, 32(5): 161-167 (in Chinese)

37. Wu R M, Wang Y P, Li F M, Li X G. Effects of coupling filmmulched furrow-ridge cropping with maize straw soil-incorporation on maize yields and soil organic carbon pool at a semiarid loess site 
of China. Acta Ecologica Sinica, 2012, 32(9): 2855-2862 (in Chinese)

38. Wang L, Li L L, Gao L F, Liu J, Luo Z Z, Xie J H. Effect of longterm conservation tillage on total organic carbon and readily oxidizable organic carbon in loess soils. Chinese Journal of EcoAgriculture, 2013, 21(9): 1057-1063 (in Chinese)

39. Zhang J Y, Sun J J, Wang J L, Fang Q X. Effect of no-tillage with straw mulching on soil water content and temperature and crop yield in semi-humid area. Chinese Agricultural Science Bulletin, 2016, 32 (3): 71-78 (in Chinese)
40. Zhang C E, Liang Y L, He X B. Effects of plastic cover cultivation on soil microbial biomass. Acta Ecologica Sinica, 2002, 22(4): 508512 (in Chinese)

41. Shi J G, Liu J H, Shi J Q, Sun Y Q, Jia L X, Rong X P. Effects of reused plastic film mulching on soil microbial biomass carbon content. Crops, 2014(5): 75-79 (in Chinese)

42. Dong B, Zeng J, Zhang D W, Guo T W, Bao X G. Effects of notillage and wheat-maze rotation on soil organic carbon, soil inorganic carbon and microbial biomass carbon contents. Chinese Journal of Soil Science, 2013, 44(2): 376-379 (in Chinese) 